\title{
Interactive effects on organic matter processing from soils to the ocean: are priming effects relevant in aquatic ecosystems?
}

\author{
Mia M. Bengtsson $(\mathbb{D} \cdot$ Katrin Attermeyer $\mathbb{B} \cdot$ Núria Catalán $\mathbb{D}$
}

Received: 29 January 2018/Revised: 16 May 2018/Accepted: 28 May 2018/Published online: 8 June 2018

(C) The Author(s) 2018

\begin{abstract}
Organic matter (OM) is degraded during transport from soils to oceans. However, there are spatial and temporal variabilities along the aquatic continuum, which hamper the development of carbon cycling models. One concept that has been applied in this context is the priming effect (PE), describing nonadditive effects on $\mathrm{OM}$ degradation after mixing sources of contrasting bioavailability. Studies on the aquatic PE report divergent results from positive (increased $\mathrm{OM}$ degradation rates) to neutral, to negative (decreased $\mathrm{OM}$ degradation rates) effects upon mixing. Here, we aim to condense the outcomes
\end{abstract}

Handling editor: Stefano Amalfitano

All authors contributed equally to the work, and the author order was determined by coin-flip.

Electronic supplementary material The online version of this article (https://doi.org/10.1007/s10750-018-3672-2) contains supplementary material, which is available to authorized users.

M. M. Bengtsson

Institute of Microbiology, University of Greifswald, Felix-Hausdorff-Straße 8, 17489 Greifswald, Germany

K. Attermeyer ( $\square)$

Limnology/Department of Ecology and Genetics, Uppsala University, Norbyvägen 18D, 75236 Uppsala, Sweden e-mail: katrin.attermeyer@wcl.ac.at of these studies on aquatic PE. Based on a literature review, we discuss differences in the reported PEs across freshwater and marine ecosystems, identifying system-specific features that could favour non-additive effects on $\mathrm{OM}$ degradation. Using a quantitative meta-analysis approach, we evaluated the occurrence, direction (positive vs. negative) and magnitude of aquatic PE. The meta-analysis revealed a mean PE of $12.6 \%$, which was not significantly different from zero across studies. Hence, mixing of contrasting $\mathrm{OM}$ sources in aquatic ecosystems does not necessarily result in a change in OM degradation rates. Therefore, we suggest to focus on molecular and microbial diversity and function, which could provide a better mechanistic understanding of processes driving $\mathrm{OM}$ interactions.

Keywords Aquatic continuum $\cdot \mathrm{DOM} \cdot$ Ecotones . Priming effect $\cdot$ Soil

Present Address:

K. Attermeyer

WasserCluster Lunz, Dr. Carl Kupelwieser Promenade 5, 3293 Lunz am See, Austria

N. Catalán

Catalan Institute for Water Research (ICRA), Emili Grahit 101, 17003 Girona, Spain 


\section{Introduction}

Organic matter (OM) is one of the largest active reservoirs of carbon (C) on earth (Ciais et al., 2013), and its dissolved fraction (DOC) represents the main form in the ocean (Hedges, 1992) and in most inland water systems (Tranvik et al., 2009). Aquatic ecosystems, including groundwater, floodplains, streams, rivers, lakes, wetlands, estuaries and oceans, process vast amounts of OM from different sources (Billen et al., 1991; Cole et al., 2007). These ecosystems are highly connected and in the transitions between them, $\mathrm{OM}$ and microbial communities from different sources continuously mix. These places and moments of mixing can be referred to as ecotones (Clements, 1905) or as ecohydrological interfaces when considering their dynamic character (Krause et al., 2017). Some examples of the interactions of different OM sources in these ecotones or ecohydrological interfaces are groundwater rich in terrigenous OM meeting streambed biofilm algae in headwater streams (Bengtsson et al., 2014; Wagner et al. 2017); leaf litter in streams, rivers and lakes being degraded in the presence of locally produced algal material (Danger et al., 2013); sediments receiving pulses of OM from the above water column, such as phytoplankton bloom debris (e.g. Gontikaki et al., 2013, 2015); or soil leaching linked, for example, to permafrost melting (Mann et al., 2015) that brings ancient fossil $\mathrm{C}$ in contact with modern aquatic C (McCallister \& del Giorgio, 2012).

The degradation dynamics of each of these OM pools separately are highly relevant as they constitute significant fractions of local and global C stocks. Even moderate changes in degradation rates can affect the $\mathrm{C}$ sequestration and ultimately the dynamics of the C-climate system. A first attempt to implement soil PE into Earth System models has revealed a prospective $51 \%$ reduction in $\mathrm{C}$ sequestration in soils during 1901-2010 linked to PEs (Guenet et al., 2018). These results in soils highlight the potential ecological relevance of non-additive effects on OM degradation rates. However, what happens when OM pools meet at ecotones or ecohydrological interfaces of aquatic environments remains largely unclear. It has been suggested that there is potential for non-additive effects on microbial degradation rates due to interaction between different $\mathrm{OM}$ pools in various aquatic environments (Guenet et al., 2010; Bianchi, 2011). By non-additive effects, we refer to a change in the degradation rates of OM after mixing in comparison to the rates of the sources without mixing, leading to either an increase (positive effect) or a decrease (negative effect) of $\mathrm{OM}$ degradation rates. Such effects have also been termed as the "priming effect" (PE; Kuzyakov et al., 2000). A PE is commonly understood as an increase in OM microbial mineralization rates (i.e. positive $\mathrm{PE}$ ). Yet, decreases in $\mathrm{OM}$ mineralization upon mixing of $\mathrm{OM}$ sources have also been acknowledged and included in the definition and have been referred to as negative PE (Blagodatskaya \& Kuzyakov, 2008) or anti-priming (Steen et al., 2016). Since positive effects have the potential to alter local and global carbon cycling, by enhancing the mineralization of terrestrial carbon sources (Bianchi, 2011), there is reason to suspect a bias towards the reporting of positive effects in the literature.

The PE concept originated in soil science (Löhnis, 1926; Bingeman et al., 1953; Kuzyakov et al., 2000; Kuzyakov, 2010), and it has only recently crossed the barrier between terrestrial and aquatic sciences (Guenet et al., 2010; Bianchi, 2011). When Guenet et al. (2010) proposed to revive the PE concept for aquatic ecosystems, it was mainly referring to the effects of the addition of labile OM on the turnover of the so-called "recalcitrant" OM pool, denoting that the latter was inherently resistant to microbial degradation. Several mechanisms based on changes in the microbial community's functions and interactions, such as co-metabolism or nutrient scavenging, were proposed to explain positive $\mathrm{PE}$ in aquatic ecosystems (see Guenet et al., 2010 or Bianchi 2011 for details). However, since Guenet et al. (2010), many studies were published on the aquatic PE with divergent results, calling for a first analysis of the applicability of the PE concept in aquatic ecosystems.

In this review, we summarize recent work addressing the PE in natural aquatic ecosystems through a literature review and subsequent meta-analysis. We aim to draw general conclusions about the prevalence and relevance of non-additive effects on degradation of $\mathrm{OM}$ pools along the aquatic continuum. We find that the overall PE is not significant across environments along the aquatic continuum, despite an apparent bias in the reporting towards positive results. These results question the relevance of the PE as a unifying concept to understand microbial degradation of interacting aquatic OM pools. The various drivers of these 
interactions across environments are discussed, to finally outline alternative conceptual avenues that may better describe non-additive interactions of OM pools occurring at ecotones of aquatic ecosystems.

\section{A research synthesis on priming effects in aquatic ecosystems}

\section{Literature review}

Relevant studies on the aquatic PE were compiled using the electronic database ISI Web of Science ${ }^{\mathrm{TM}}$, as well as previous compilations on PE (such as Guenet et al., 2010; Blanchet et al., 2017) and subsequent searches based on cited papers. A search on ISI Web of Science $^{\mathrm{TM}}$ on 6th April 2018 using [(aquatic OR lake OR rive* OR inland wat*) AND ("priming effect")] found a total of 73 studies. Of these, 48 studies were published after 2010 , constituting about $65 \%$ of the total, highlighting the increased interest in the aquatic PE since the review by Guenet et al. (2010). From these studies, we included 26 in our narrative review. These studies specifically mentioned PE in their aims, hypotheses or keywords. This helps to reduce publication bias towards positive PE, as studies not designed to test priming might include the concept of PE in their discussion only if a positive PE was indicated. We categorized data in these studies by aquatic ecosystem type (culture, stream, river, lake, or marine including estuaries), material (litter, sediment, water), nutrients manipulation (yes or no), and the sources of labile and recalcitrant C. Finally, we produced a categorical variable "positive, negative or non-significant" priming. The result of this compilation is presented in Table 1, and allowed to qualitatively summarize the results of $\mathrm{PE}$ in aquatic ecosystems.

PE data retrieval and calculations

With the objective to quantitatively estimate the magnitude of aquatic PE, we selected those studies that used (i) bacterial respiration based on $\mathrm{CO}_{2}$ production or oxygen consumption, or (ii) organic carbon (OC) loss over time -either as DOC or as litter mass- to report OC degradation. Moreover, these measures resolve OC degradation of one defined OC pool of interest (normally the "recalcitrant" pool), through stable isotope labelling of OC pools or other appropriate approaches such as modelling. Values of the OC degradation parameters for each observation and the corresponding control were retrieved. Time steps in incubations (i.e. repeated measures) were aggregated as one overall mean according to Huo et al. (2017):

$M=\sum_{i=1}^{j} \frac{\mathrm{Mi}}{j}$,

where $M$ is the overall mean, Mi the mean on the $i$ th sampling time and $j$ the number of repeated measures under one treatment. Treatments with the same $\mathrm{C}$ sources but different nutrient amendments were considered separately. A total of 17 studies and 118 observations were included in the calculations (and subsequent meta-analysis, see below). Data point values were extracted directly from tables or from figures using the WebPlotDigitizer app (http:// arohatgi.info/WebPlotDigitizer/app/; November 6th, 2016), except where raw data were made available directly by the authors.

Since OC degradation was reported in a variety of different units (e.g. g leaf mass loss, g C respired, $\mathrm{g}$ DOC removed), we calculated the $\mathrm{PE}$ as a percentage of background or control OC degradation according to

$\mathrm{PE}=\left(R_{\mathrm{PE}} / R_{\mathrm{C}}\right) * 100$,

where PE refers to the priming effect (in \%), $R_{\mathrm{PE}}$ to the difference between the priming treatment and the control for a given OC degradation parameter and thus represents the positive or negative change in a priming treatment, and $R_{\mathrm{C}}$ the $\mathrm{OC}$ degradation in a control treatment containing the OC pool of interest (often the "recalcitrant" pool) without added primer (i.e. "labile" pool). Violin plots (Hintze \& Nelson, 1998) were used in order to visualize the density distributions of the PE expressed as \% across aquatic ecosystem type along the aquatic continuum (Fig. 1a) and the materials (i.e. litter, sediment or water) used for experimentation (Fig. 1b).

PE in different environments along the aquatic continuum

Each ecosystem type along the aquatic continuum, from streams to the ocean, has different ecotones (or ecohydrological interfaces) and mechanisms that 
Table 1 A summary of studies addressing the priming effect in an aquatic context and their outcomes

\begin{tabular}{|c|c|c|c|c|c|c|c|c|c|c|c|}
\hline & Reference & $\begin{array}{l}\text { Experiment } \\
\text { al unit }\end{array}$ & $\begin{array}{c}\text { Aquatic } \\
\text { ecosystem }\end{array}$ & Habitat & $\begin{array}{l}\text { PE (+/- } \\
/ \pm / \text { NO) }\end{array}$ & \begin{tabular}{|} 
Nutrien \\
ts \\
added?
\end{tabular} & $\begin{array}{c}\text { Labile C } \\
\text { source }\end{array}$ & $\begin{array}{l}\text { Recalcitrant } \mathrm{C} \\
\text { source }\end{array}$ & $\begin{array}{c}{ }^{13} \mathrm{C} \\
\text { labeled? }\end{array}$ & $\begin{array}{c}\text { Microbial } \\
\text { community }\end{array}$ & \begin{tabular}{|c|} 
Parameter \\
used to detect \\
PE \\
\end{tabular} \\
\hline \multirow{8}{*}{ 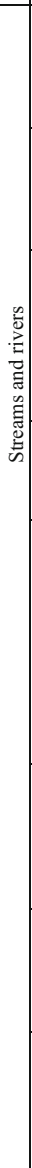 } & $\begin{array}{l}\text { Bengtsson et al. } \\
2014\end{array}$ & lab & $\begin{array}{l}\text { stream, } \\
\text { hyporheic } \\
\text { zone }\end{array}$ & biofilm & NO & YES & $\begin{array}{l}\text { glucose and } \\
\text { algal extract }\end{array}$ & $\begin{array}{l}\text { leaf and stem } \\
\text { extract from } \\
\text { crack willow } \\
\text { (Salix fragilis) }\end{array}$ & $\begin{array}{c}\text { YES }= \\
\text { recalcitran } \\
t\end{array}$ & $\begin{array}{l}\text { natural microbial } \\
\text { community on glass } \\
\text { beads: Oberer } \\
\text { Seebach (Lunz am } \\
\text { See, Austria) }\end{array}$ & \begin{tabular}{|l} 
microbial \\
respiration and \\
recalcitrant \\
DOM removal
\end{tabular} \\
\hline & $\begin{array}{c}\text { Danger et al. } \\
2013\end{array}$ & lab & stream & sediment & \pm & YES & $\begin{array}{c}\text { living diatom } \\
\text { algae } \\
\text { (Nitzschia } \\
\text { palea) }\end{array}$ & $\begin{array}{l}\text { freshly abscised, } \\
\text { air-dried leaves of } \\
\text { alder (Alnus } \\
\text { glutinosa Gaertn.) }\end{array}$ & NO & \begin{tabular}{|c|} 
six fungal \\
hyphomycetes and/or \\
assemblages of stream \\
bacteria filtered over \\
GF/C (France)
\end{tabular} & $\begin{array}{c}\text { leaf litter mass } \\
\text { loss }\end{array}$ \\
\hline & $\begin{array}{c}\text { Franke et al. } \\
2013\end{array}$ & lab & river basin & biofilm & $\begin{array}{l}\mathrm{NO}(+ \text { in } \\
\text { some) }\end{array}$ & YES & glucose & $\begin{array}{l}\text { ambient stream } \\
\text { DOC }\end{array}$ & NO & \begin{tabular}{|c|} 
natural microbial \\
biofilm community \\
grown on tiles before \\
experiment (Humber \\
River Basin in western \\
Newfoundland, \\
Canada) \\
\end{tabular} & $\begin{array}{c}\mathrm{CO}_{2} \\
\text { production }\end{array}$ \\
\hline & $\begin{array}{l}\text { Halvorson et al. } \\
2016\end{array}$ & lab & stream & $\begin{array}{l}\text { plant } \\
\text { litter }\end{array}$ & + & YES & \begin{tabular}{|c|} 
algal \\
exudates \\
stimulated by \\
light \\
\end{tabular} & maple leaf litter & NO & $\begin{array}{c}\text { stream water; Jones } \\
\text { Creek, third-order } \\
\text { stream (Winfrey, } \\
\text { Arkansas, U.S.A.) } \\
\end{array}$ & $\begin{array}{c}\text { litter } \\
\text { mineralization } \\
\text { rates }\end{array}$ \\
\hline & $\begin{array}{l}\text { Hotchkiss et al. } \\
\qquad 2014\end{array}$ & lab + model & river & water & \pm & YES & \begin{tabular}{|} 
leachates \\
from \\
dominant \\
river algae or \\
macrophyte \\
assemblages \\
and glucose \\
(corn sugar)
\end{tabular} & $\begin{array}{c}\text { ambient river } \\
\text { DOC and/or } \\
\text { commercially } \\
\text { available humate } \\
\text { extract (Nature's } \\
\text { Solution Ancient } \\
\text { Humate, Nature } \\
\text { Technologies } \\
\text { International } \\
\text { LLC) }\end{array}$ & NO & $\begin{array}{c}\text { inoculum from } \mathrm{GF} / \mathrm{F} \\
\text { filtered river water } \\
\text { (five rivers in the } \\
\text { Midwestern United } \\
\text { States and five rivers } \\
\text { in the western United } \\
\text { States) }\end{array}$ & $\begin{array}{c}\text { DOC } \\
\text { degradation }\end{array}$ \\
\hline & $\begin{array}{c}\text { Stutter and Cains } \\
2015\end{array}$ & lab & $\begin{array}{l}\text { river, } \\
\text { benthic }\end{array}$ & sediment & mainly + & YES & $\begin{array}{l}\text { fulvic acid, } \\
\text { DOM }_{\text {Pond }} \\
\text { DOM }_{\text {Moor }}, \\
\text { DOM }_{\text {Agr }} \\
\text { DOM } \\
\text { glucosest }\end{array}$ & $\begin{array}{c}\text { ambient sediment } \\
\text { C }\end{array}$ & NO & $\begin{array}{c}\text { natural microbial } \\
\text { community from } \\
\text { stream sediment (NE } \\
\text { Scotland) }\end{array}$ & $\begin{array}{l}\text { bacterial } \\
\text { respiration and } \\
\mathrm{C} \text { mass } \\
\text { balance }\end{array}$ \\
\hline & $\begin{array}{c}\text { Wagner et al. } \\
2017\end{array}$ & lab & stream & biofilm & NO & $\mathrm{NO}$ & $\begin{array}{c}\text { natural algal } \\
\text { biofilm } \\
\text { induced by } \\
\text { light }\end{array}$ & $\begin{array}{l}\text { Cold water } \\
\text { extract from } \\
\text { willow (Salix } \\
\text { fragilis) }\end{array}$ & $\begin{array}{c}\text { YES }= \\
\text { recalcitran } \\
t\end{array}$ & $\begin{array}{c}\text { natural biofilm } \\
\text { community on glass } \\
\text { slides: Oberer } \\
\text { Seebach (Lunz am } \\
\text { See, Austria) } \\
\end{array}$ & mass balance \\
\hline & $\begin{array}{l}\text { Ward et al. } \\
\quad 2016\end{array}$ & lab & river & water & + & NO & algal solution & $\begin{array}{l}\text { riverine DOM + } \\
\text { vanillin; four } \\
\text { different plant } \\
\text { litter leachates }\end{array}$ & $\begin{array}{c}\text { YES }= \\
\text { recalcitran } \\
\mathrm{t}\end{array}$ & $\begin{array}{c}\text { natural microbial } \\
\text { community; Amazon } \\
\text { river stations }\end{array}$ & $\begin{array}{l}\text { headspace } \\
\mathrm{pCO}_{2} \\
\text { production }\end{array}$ \\
\hline \multirow{5}{*}{ 包 } & $\begin{array}{c}\text { Bianchi et al. } \\
2015\end{array}$ & lab & $\begin{array}{c}\text { bacterial } \\
\text { culture }\end{array}$ & water & + & NO & \begin{tabular}{|c|} 
trehalose, \\
diatom \\
leachate from \\
Phaeodactylu \\
$m$ \\
tricornutum \\
\end{tabular} & $\begin{array}{c}\text { leachate from } \\
\text { loblolly pine tree } \\
\text { (Pinustaeda) } \\
\text { needles }\end{array}$ & $\begin{array}{l}\text { YES }= \\
\text { labile }\end{array}$ & $\begin{array}{l}\text { cultured bacterium: } \\
\text { Acinetobacter } \text { sp. } \\
\text { MR1 enrichment on } \\
\text { basal medium }\end{array}$ & $\begin{array}{c}\text { TDOC } \\
\text { remineralizatio } \\
\text { n rate }\end{array}$ \\
\hline & $\begin{array}{c}\text { Catalán et al. } \\
2015\end{array}$ & lab & $\begin{array}{l}\text { lake and } \\
\text { river }\end{array}$ & water & NO & YES & $\begin{array}{l}\text { acetate, } \\
\text { glucose, and } \\
\text { cellobiose }\end{array}$ & $\begin{array}{l}\text { ambient boreal } \\
\text { lake DOC and a } \\
\text { reverse osmosis } \\
\text { river DOM } \\
\text { extract } \\
\end{array}$ & NO & $\begin{array}{c}\text { natural microbial } \\
\text { community inoculated } \\
(1: 10) \text { from three } \\
\text { lakes (central Sweden) }\end{array}$ & $\begin{array}{c}\text { DOC } \\
\text { consumed } \\
\text { during } \\
\text { incubation }\end{array}$ \\
\hline & $\begin{array}{c}\text { Dorado-García et } \\
\text { al. } \\
2015\end{array}$ & $\begin{array}{l}\text { Field } \\
\text { mesocosms }\end{array}$ & lake, humic & water & NO & NO & cane sugar & $\begin{array}{l}\text { ambient humic } \\
\text { lake water }\end{array}$ & $\begin{array}{l}\text { YES }= \\
\text { labile }\end{array}$ & $\begin{array}{c}\text { natural microbial } \\
\text { community; humic } \\
\text { lake Mekkojärvi } \\
\text { (Finland) }\end{array}$ & $\begin{array}{l}\text { no distinction } \\
\text { between } \\
\text { recalcitrant } \\
\text { and labile C } \\
\text { pool }\end{array}$ \\
\hline & $\begin{array}{c}\text { Guenet et al. } \\
2014\end{array}$ & lab & lake & water & + & NO & glucose & soil leachate & $\begin{array}{l}\text { YES }= \\
\text { labile }\end{array}$ & \begin{tabular}{|c|} 
inoculum from natural \\
GF/F filtered \\
microbial community \\
(Lake Créteil, France) \\
\end{tabular} & \begin{tabular}{|c|}
$\mathrm{CO}_{2}$ \\
production \\
from soil \\
mineralization \\
\end{tabular} \\
\hline & $\begin{array}{c}\text { Kankaala et al. } \\
2013\end{array}$ & field & lake & water & + & NO & $\begin{array}{l}\text { algal } \\
\text { exudates }\end{array}$ & $\begin{array}{c}\text { ambient lake } \\
\text { DOC }\end{array}$ & NO & $\begin{array}{c}\text { natural microbial } \\
\text { community in five } \\
\text { boreal lakes (southern } \\
\text { Finland) }\end{array}$ & \begin{tabular}{|c} 
Direct \\
parameter \\
absent \\
(evaluate \\
relationship \\
between \\
primary \\
production and \\
heterotrophic \\
production) \\
\end{tabular} \\
\hline
\end{tabular}


Table 1 continued

\begin{tabular}{|c|c|c|c|c|c|c|c|c|c|c|c|}
\hline & $\begin{array}{l}\text { Morling et al. } \\
2017\end{array}$ & lab & $\begin{array}{l}\text { reservoir } \\
\text { inflow/outfl } \\
\text { ow }\end{array}$ & water & + & YES & $\begin{array}{c}\text { naturally } \\
\text { growing } \\
\text { phytoplankto } \\
\mathrm{n}\end{array}$ & $\begin{array}{l}\text { peat water; soil } \\
\text { leachate }\end{array}$ & $\underset{{ }^{14} \mathrm{C}}{\mathrm{NO} \text {, but }}$ & $\begin{array}{c}\text { mixed natural } \\
\text { bacterioplankton; } \\
\text { inflow and outflow of } \\
\text { reservoirs (Germany) }\end{array}$ & $\begin{array}{c}\text { natural } \\
\text { abundance }{ }^{14} \mathrm{C} \\
\text { analysis and } \\
\text { isotope mixing } \\
\text { models } \\
\end{array}$ \\
\hline & Soares et al. 2017 & lab & pond & biofilm & $\mathrm{NO}$ & $\mathrm{NO}$ & $\begin{array}{c}\text { natural algal } \\
\text { community; } \\
\text { glucose } \\
\end{array}$ & maize litter & NO & $\begin{array}{c}\text { natural microbial } \\
\text { community from pond } \\
\text { (Sweden) }\end{array}$ & litter mass loss \\
\hline \multirow{3}{*}{ 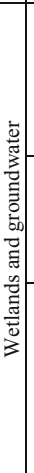 } & $\begin{array}{l}\text { Hofmann and } \\
\text { Griebler } 2018\end{array}$ & lab & $\begin{array}{c}\text { groundwate } \\
\mathrm{r}\end{array}$ & water & NO & YES & $\begin{array}{l}\text { acetate, } \\
\text { organic } \\
\text { fertilizer, } \\
\text { fulvic and } \\
\text { humic acids }\end{array}$ & $\begin{array}{c}\text { ambient } \\
\text { groundwater } \\
\text { DOC }\end{array}$ & NO & $\begin{array}{l}\text { natural microbial } \\
\text { community from the } \\
\text { groundwater }\end{array}$ & $\begin{array}{c}\text { DOC } \\
\text { production, } \\
\text { bacterial } \\
\text { abundance and } \\
\text { growth } \\
\text { efficiency } \\
\end{array}$ \\
\hline & $\begin{array}{l}\text { Kuehn et al. } \\
2014\end{array}$ & lab & $\begin{array}{l}\text { freshwater } \\
\text { marsh }\end{array}$ & $\begin{array}{l}\text { plant } \\
\text { litter, } \\
\text { periphyt } \\
\text { on }\end{array}$ & + & $\mathrm{NO}$ & $\begin{array}{c}\text { periphytic } \\
\text { algal } \\
\text { exudation } \\
\text { stimulated by } \\
\text { light } \\
\end{array}$ & $\begin{array}{c}\text { plant litter of } \\
\text { Typha } \\
\text { angustifolia and } \\
\text { Schoenoplectus } \\
\text { acutus } \\
\end{array}$ & NO & $\begin{array}{c}\text { natural biofilm } \\
\text { community; } \\
\text { freshwater marsh } \\
\text { (southeast Michigan, } \\
\text { USA) } \\
\end{array}$ & $\begin{array}{l}\text { fungal growth } \\
\text { rates (\% per } \\
\text { hour) at } 29 \mathrm{~d}\end{array}$ \\
\hline & $\begin{array}{l}\text { Wyatt and } \\
\text { Turetski } \\
2015\end{array}$ & $\begin{array}{c}\text { field } \\
\text { mesocosms }\end{array}$ & peatland & $\begin{array}{l}\text { plant } \\
\text { litter }\end{array}$ & + & YES & $\begin{array}{l}\text { algal primary } \\
\text { production } \\
\text { and glucose }\end{array}$ & $\begin{array}{l}\text { Over-wintered } \\
\text { standing-dead } \\
\text { stems of Carex } \\
\text { utriculata }\end{array}$ & NO & $\begin{array}{c}\text { natural microbial } \\
\text { community from } \\
\text { incubation in poor fen } \\
\text { within the floodplain } \\
\text { of the Tanana River } \\
\text { (Fairbanks, Alaska, } \\
\text { USA) }\end{array}$ & $\begin{array}{l}\text { bacterial } \\
\text { respiration, } \\
\text { biomass and } \\
\text { DOC }\end{array}$ \\
\hline \multirow{7}{*}{ 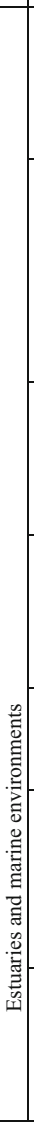 } & $\begin{array}{c}\text { Blanchet et al. } \\
2017\end{array}$ & lab & $\begin{array}{l}\text { marine, } \\
\text { estuary }\end{array}$ & water & NO & $\mathrm{NO}$ & amino acids & riverine $\mathrm{DOM}$ & NO & $\begin{array}{c}\text { surface water; coastal } \\
\text { station in the NW } \\
\text { Mediterranean Sea } \\
\text { (SOLA station, in the } \\
\text { Bay of Banyuls-sur- } \\
\text { Mer, France) } \\
\end{array}$ & $\begin{array}{c}\text { DOC } \\
\text { degradation }\end{array}$ \\
\hline & $\begin{array}{l}\text { Gontikaki et al. } \\
2013\end{array}$ & lab & marine & $\begin{array}{l}\text { sediment } \\
\text {, oxic }\end{array}$ & NO & $\mathrm{NO}$ & $\begin{array}{l}\text { diatom } \\
\text { Thalassiosira } \\
\text { rotula }\end{array}$ & $\begin{array}{c}\text { ambient sediment } \\
\text { C }\end{array}$ & $\begin{array}{l}\text { YES }= \\
\text { labile }\end{array}$ & $\begin{array}{c}\text { natural microbial } \\
\text { community; top } 3 \mathrm{~cm} \\
\text { (northern Rockall } \\
\text { Trough, NE Atlantic) }\end{array}$ & $\begin{array}{c}\mathrm{CO}_{2} \\
\text { production }\end{array}$ \\
\hline & $\begin{array}{c}\text { Gontikaki et al. } \\
2015\end{array}$ & lab & marine & $\begin{array}{l}\text { sediment } \\
\text { s, oxic }\end{array}$ & + & $\mathrm{NO}$ & $\begin{array}{l}\text { freeze-dried } \\
\text { biomass of } \\
\text { the diatom } \\
\text { Thalassiosira } \\
\text { pseudonana }\end{array}$ & lignocellulose & $\begin{array}{c}\mathrm{YES}= \\
\text { recalcitran } \\
\mathrm{t}\end{array}$ & $\begin{array}{c}\text { natural microbial } \\
\text { community; lower } \\
\text { reach of the Ythan } \\
\text { estuary } \\
\text { (Aberdeenshire, } \\
\text { Scotland, UK) }\end{array}$ & $\begin{array}{c}\mathrm{CO}_{2} \\
\text { production }\end{array}$ \\
\hline & $\begin{array}{l}\text { Hannides and } \\
\text { Aller } 2016\end{array}$ & lab & marine & $\begin{array}{l}\text { sediment } \\
\text {, anoxic }\end{array}$ & + & $\mathrm{NO}$ & $\begin{array}{l}\text { mucus of the } \\
\text { gastropod } \\
\text { Neverita } \\
\text { duplicata }\end{array}$ & ambient sediment & NO & $\begin{array}{l}\text { anoxic sediment from } \\
\text { a mudflat in Flax } \\
\text { Pond, back-barrier } \\
\text { estuarine lagoon and } \\
\text { salt marsh; Long } \\
\text { Island, NY. } \\
\end{array}$ & $\begin{array}{c}\mathrm{CO}_{2} \\
\text { production }\end{array}$ \\
\hline & $\begin{array}{l}\text { Koch et al. } \\
2014\end{array}$ & lab & marine & water & NO & $\mathrm{NO}$ & glucose & $\begin{array}{c}\text { Recalcitrant } \\
\text { compounds } \\
\text { generated by } \\
\text { microbial C pump } \\
\end{array}$ & NO & $\begin{array}{c}\text { natural microbial } \\
\text { community; Antarctic } \\
\text { surface water }\end{array}$ & $\begin{array}{c}\text { DOC } \\
\text { degradation }\end{array}$ \\
\hline & $\begin{array}{l}\text { Steen et al. } \\
\quad 2016\end{array}$ & lab & $\begin{array}{l}\text { marine, } \\
\text { estuary }\end{array}$ & water & \pm & YES & $\begin{array}{l}\text { sodium } \\
\text { acetate or } \\
\text { protein } \\
(\mathrm{BSA})\end{array}$ & $\begin{array}{c}\text { microbially- } \\
\text { degraded, } \\
\text { recalcitrant }{ }^{14} \mathrm{C}- \\
\text { labeled } \\
\text { phytoplankton } \\
\text { necromass } 1 \mathrm{mM} \\
\mathrm{PO}^{14} \mathrm{C} \\
\end{array}$ & $\begin{array}{c}\mathrm{NO} \text { but } \\
{ }^{14} \mathrm{C}= \\
\text { recalcitran } \\
\mathrm{t}\end{array}$ & $\begin{array}{l}\text { natural microbial } \\
\text { community inoculum } \\
\text { (Bogue Sound, NC) }\end{array}$ & $\begin{array}{c}\mathrm{CO}_{2} \\
\text { production }\end{array}$ \\
\hline & $\begin{array}{c}\text { Trevathan- } \\
\text { Tackett et al. } \\
2018\end{array}$ & lab & marine & sediment & \pm & $\mathrm{NO}$ & $\begin{array}{c}\text { seagrass } \\
\text { Zostera } \\
\text { muelleri; } \\
\text { microalgae } \\
\text { Chlorella } \\
\text { vulgaris } \\
\end{array}$ & $\begin{array}{c}\text { ambient sediment } \\
\text { OC }\end{array}$ & $\begin{array}{l}\text { YES }= \\
\text { labile }\end{array}$ & $\begin{array}{l}\text { Natural microbial } \\
\text { community; Fagans } \\
\text { Bay, New South } \\
\text { Wales, Australia }\end{array}$ & $\begin{array}{c}\mathrm{CO}_{2} \\
\text { production }\end{array}$ \\
\hline & $\begin{array}{c}\text { Van Nugteren et } \\
\text { al. } \\
2009\end{array}$ & lab & marine & sediment & + & NO & \begin{tabular}{|c|} 
cultured \\
diatom \\
Skeletonema \\
costatum \\
\end{tabular} & $\begin{array}{c}\text { natural sediment } \\
\text { C }\end{array}$ & $\begin{array}{l}\text { YES = } \\
\text { labile }\end{array}$ & $\begin{array}{l}\text { natural microbial } \\
\text { community; } \\
\text { Skagerrak, eastern } \\
\text { North Sea }\end{array}$ & $\begin{array}{c}\mathrm{CO}_{2} \\
\text { production }\end{array}$ \\
\hline
\end{tabular}

\footnotetext{
Studies included in meta-analysis are highlighted in bold
} 


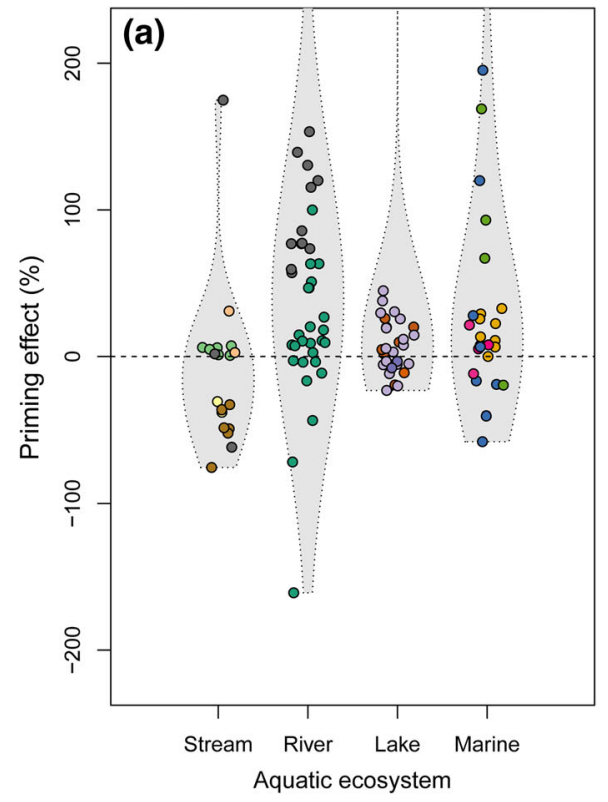

Fig. 1 The priming effect in \% of background OC processing for all studies carried out in an aquatic context where PE could be calculated. In a, the results are plotted according to ecological context along the aquatic continuum, while in $\mathbf{b}$, the same results

might affect non-additive interactions of OM pools. Therefore, we review the studies addressing PE separated by ecosystem types in order to better understand the potential for non-additive effects in individual environments.

\section{Streams and rivers}

Streams and rivers generally have high flow through and low water retention times, which exert a strong control on OC decomposition rates (Catalán et al., 2016). On a continental scale, streams and rivers themselves are ecotones, closely connecting terrestrial and aquatic ecosystems. From the River Continuum Concept, most reactions are expected to occur in loworder headwater streams (Vannote et al., 1980). Headwater streams also receive the main OC subsidies from terrestrial sources, which largely drive the OM turnover (Vannote et al., 1980). Perhaps this is why most studies dealing with PEs in streams and rivers were conducted in the context of headwater streams, mimicking the conditions of stream sediments (hyporheic zone, Bengtsson et al., 2014), benthic biofilms (Franke et al., 2013; Wagner et al., 2017) or decaying leaf litter (Danger et al., 2013; Halvorson et al., 2016).

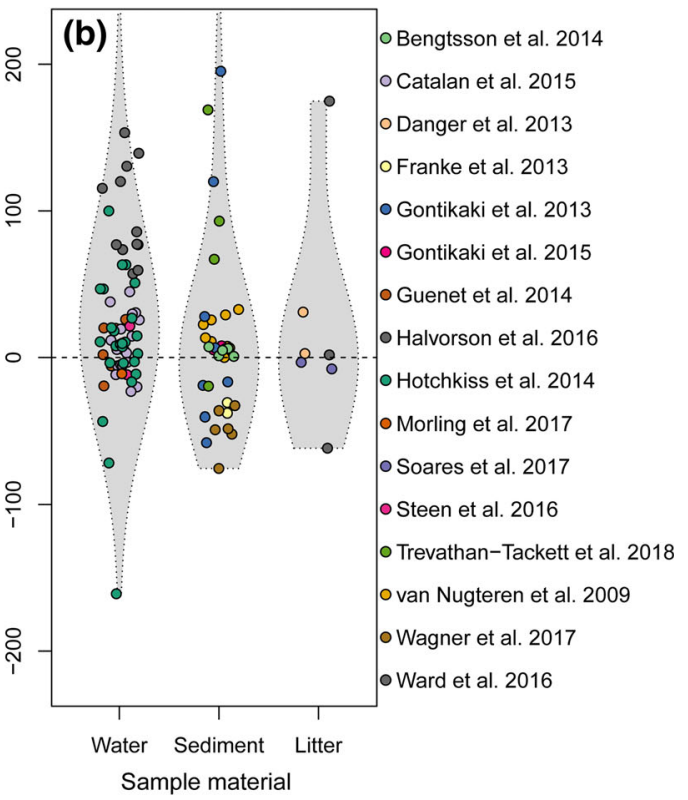

are plotted according to sample material. Data point distribution is illustrated using kernel density traces (violin plots). For visual purposes, outliers (data points $>700 \%$ ) are not shown

The average PE detected in stream studies was-9.9\% (median $=0.7 \%$, interquartile $(\mathrm{IQ})$ range $=[-43.1$, 5.4], $n=19$, Fig. 1a), whereas the reported interpretation of PEs varied from negative (Wagner et al., 2017), to neutral (Bengtsson et al., 2014; Wagner et al., 2017) to positive (Danger et al., 2013; Franke et al., 2013).

The Pulse Shunt Concept (Raymond et al., 2016), however, suggests that the role of streams and rivers as reactors or inactive pipes is based on hydrological variability. This implies that hotspots of OM turnover can be displaced from the upper to the lower reaches or even to the ocean (Raymond et al., 2016). However, relatively few studies have addressed PEs in larger rivers. Stutter \& Cains (2015) found both positive and negative PE when incubating river sediment with glucose, fulvic acids and dissolved organic matter (DOM) sources from different aquatic ecosystems. Hotchkiss et al. (2014) tested PE in a river-water context using bioassays containing mixes of river DOM, soil leachates, commercial humate, algal exudates and glucose in different combinations and employing a Bayesian modelling approach to separate the degradation of the different $\mathrm{C}$ pools. They found variable, yet on average positive PE of both native 
river DOM, soil leachates and commercial humate. Ward et al. (2016) performed incubation experiments with river water, ${ }^{13} \mathrm{C}$-labelled substrates (vanillin, vascular plant leachates) and algal leachates from the lower Amazon River. They reported PE based on short-term incubations ( $\sim 6$ to $10 \mathrm{~h}$ ) supported by in situ observed increases in $\mathrm{O}_{2}$ drawdown and $\mathrm{CO}_{2}$ production at river confluences. On average, the detected PE in these two studies (Hotchkiss et al., 2014; Ward et al., 2016), taking place in larger rivers was $99.5 \%$ (median $=46.8 \%$, IQ range $=[7.8,85.7]$, $n=41)$. Interestingly, a small number of data points presented very high positive PEs ( 500 to $1000 \%$ ) which were difficult to explain based on the experimental context and may warrant further investigation.

\section{Lakes}

Within lakes, three main ecotones have been considered in the context of PE, (i) inlets from streams and rivers bringing terrestrially derived, allochthonous DOM in contact with lake autochthonous DOM, (ii) phytoplankton blooms pulsing fresh autochthonous DOM that may interact with older, resident DOM and (iii) leaf litter degradation. Lakes are often considered net-heterotrophic with respiration exceeding primary production indicating that a high amount of allochthonous C can be mineralized in lakes (Cole et al., 1994; Del Giorgio et al., 1999; Tranvik et al., 2009). The decay of allochthonous $\mathrm{C}$ was also the focus of a number of the PE studies, showing that the degradation of soil and leaf leachates increased with the addition of glucose and trehalose or algal $\mathrm{C}$, respectively (Guenet et al., 2014; Bianchi et al., 2015).

The majority of the studies in lakes investigated the degradation of ambient DOM with additions of simple sugars (Catalán et al., 2015; Dorado-García et al., 2015) or algal leachates (Kankaala et al., 2013), mimicking algal blooms and the exudation of simple sugars during phases of high primary productivity. One study detected a PE when using peat water or soil leachate with naturally growing phytoplankton (Morling et al., 2017). Another study investigated the biofilm microbial community on leaves (Soares et al., 2017) and its effect on $C$ and nitrogen loss from these leaves. Here, the labile $\mathrm{C}$ produced by the algal community stimulated fungal decomposers and increased nitrogen removal from leaf litter, but not $\mathrm{C}$ removal. The average $\mathrm{PE}$ in lake studies where priming could be quantified was $23.7 \%$ (median $5.1 \%$, IQ range $=[-5.6,20.0], n=30$ ). It is worth noting that most of these studies were conducted under conditions similar to the ones in the water column, and that we are not aware of any studies in lake sediments although, especially in small and shallow lakes or ponds, benthic processes can play a major biogeochemical role (Vadeboncoeur et al., 2002).

\section{Wetlands and groundwater}

Wetlands are important transition zones between terrestrial and aquatic ecosystems and regulate nutrient and matter fluxes between them. In wetland soils, plant litter decomposition can affect physical and chemical properties (Mitsch \& Gosselink, 2007), nutrient cycling, primary productivity, and C storage capacity (Gambrell \& Patrick, 1978; Xiong \& Nilsson, 1997). A study in a peatland (Wyatt \& Turetsky, 2015) and one in a freshwater marsh (Kuehn et al., 2014) tested PE as changes in heterotrophic activities of litter-associated microbial communities with living algae stimulated by light. Both studies reported increases in the litter-associated heterotrophic activity, after the addition of either labile C (Wyatt \& Turetsky, 2015) or light (i.e. enhancing in situ algal activity; Kuehn et al., 2014; Wyatt \& Turetsky, 2015), interpreted as positive PE. Unfortunately, none of the studies conducted in wetlands reported data that allowed us to incorporate them in our meta-analysis, and therefore the magnitude of the PE in wetlands could not be evaluated.

The only study addressing PE in a groundwater context reported no indication of PE (Hofmann \& Griebler, 2018). The low number of studies addressing $\mathrm{PE}$ in this environment is surprising, since groundwater is a paradigmatic ecohydrological interface, being tightly connected to the terrestrial milieu and feeding the aquatic continuum with water and its associated OM (Moore, 1996).

\section{Estuaries and marine environments}

Estuaries constitute an ecotone where rivers meet coastal waters (Bianchi, 2011). These systems, permanently supplied with nutrients and sediments carried downstream by rivers, support high biological production and strong biogeochemical gradients (Bianchi, 2007). However, regarding PE, river DOM 
incubated with a natural bacterial community from coastal waters and addition of amino acids (Blanchet et al., 2017), produced no significant increases in bacterial activities or OC consumption. Moreover, Seidel et al. (2015) reported a significant OC decrease in the outer plume of the Amazon River but the authors relate it to photo-degradation processes. Just one study, reporting a short-term increase in OC degradation with microbially degraded phytoplankton necromass and additions of sodium acetate and protein incubated together with a coastal bacterial community in water (Steen et al., 2016), was included in our quantitative analysis.

Oceans harbour the largest pool of DOM (Hansell, 2013) and the majority of the oceanic OM is below $1,000 \mathrm{~m}$ and thousands of years old, transformed from freshly produced $\mathrm{OM}$ into presumably recalcitrant forms through the microbial C pump (Jiao et al., 2014). Arrieta et al. (2015) challenged this concept showing that the deep-sea "recalcitrant" $\mathrm{C}$, when concentrated, is readily consumed. However, Koch et al. (2014) found no positive PE in laboratory incubations with oceanic water and glucose added. In coastal areas, $\mathrm{OM}$ of terrestrial origin can make up a substantial part of the OM pool, which could be subject to PE under certain conditions such as in upwelling areas with high primary production rates (Bianchi, 2011).

Sediments offer an environment directly analogous to soils, and several studies have addressed PE in estuarine and marine sediments. Gontikaki et al. (2015) investigated the stimulating effect of a diatom species as labile $\mathrm{C}$ pulse to the sediment and lignocellulose as recalcitrant $\mathrm{C}$ and Hannides and Aller (2016) used snail mucus as a priming agent to stimulate benthic $\mathrm{C}$ turnover. Both sediment studies reported a positive PE. The first, again showing evidences of the prevalence of that effect in the first days of the incubations and the second being the first study investigating PE in aquatic ecosystems under anoxic conditions. Marine PE could be quantified only in marine sediment studies (van Nugteren et al., 2009; Gontikaki et al., 2013, 2015) and estuarine water (Steen et al., 2016) showing an average PE of $46.2 \%$ (median $12.1 \%$, IQ range $=[1.3,31.8], n=26)$.
Meta-analysis of the aquatic PE

Evidently, there is a great variety in both magnitude and direction (i.e. positive or negative) of reported PEs across aquatic ecosystems. To achieve a quantitative assessment of the relevance of overall PE in the aquatic environment, we applied a meta-analysis approach (Hillebrand \& Gurevitch, 2016) on the quantitative studies $(n=17)$ addressing aquatic PE. We specifically wanted to (i) estimate the magnitude of the PE, (ii) test if it is significantly different from zero, and (iii) evaluate potential publication biases. In order to estimate the magnitude of the aquatic PE, effect sizes were calculated as $\log$ response ratios (LRRs), according to Hedges et al. (1999):

$\mathrm{LRR}=\ln \left(X_{\mathrm{T}} / X_{\mathrm{C}}\right)$,

where $X_{\mathrm{T}}$ is the mean value of OC degradation of the treatment group (i.e. with primer) and $X_{\mathrm{C}}$ of the control group (i.e. without primer). Therefore, negative and positive effects are equally weighted and independent of the units of measurement (Gurevitch \& Hedges, 2001). We obtained the sampling variance of each study (i.e. publication) applying:

$v_{\ln R}=\frac{\left(S_{T}\right)^{2}}{N_{T} \times\left(X_{T}\right)^{2}}+\frac{\left(S_{C}\right)^{2}}{N_{C} \times\left(X_{C}\right)^{2}}$,

where $v_{\mathrm{ln} R}$ represents the sampling variance, $S_{\mathrm{T} \text { or C }}$ is the standard deviation of the treatment $(T)$ or the control $(C)$, respectively; $N_{\mathrm{C} \text { or } \mathrm{T}}$ is the number of cases in each group and $X_{\mathrm{T} \text { or } \mathrm{C}}$ is the mean response value of the treatment or the control, respectively. The numbers of replicates of each treatment and related control were used to obtain the number of cases in each study.

The weighted overall effect $E$ was estimated as the average of the weighted effect sizes divided by the sum of the weights (see details in Hillebrand \& Gurevitch, 2016). This is implemented in the rma function of the metafor package for R (Viechtbauer, 2010) through a random effects model, which we used to test whether the overall effect $E$ deviates from zero. Then, we used a mixed effects model also implemented in rma to test for differences on effect sizes due to the position in the aquatic continuum and/or the material used in the incubation.

Finally, to evaluate for publication or reporting biases, we used a funnel plot. Funnel plots represent an estimate of the size effect of a study versus an estimate 
of the variance within that study (see Duval \& Tweedie, 2000). Thus, in the absence of bias, small imprecise studies should scatter at the bottom of the graph and narrow at the top were large and precise studies would be found (Sterne \& Harbord, 2004). All the analyses were performed in R 3.2.2 (R Core Team, 2016). The code is provided as Supplementary information 1 (ESM_1).

The results of the meta-analysis showed no significant PE in aquatic studies as, despite the overall estimated average log response was positive: 0.12 (95\% CI -0.06 to 0.29 ), or expressed as \% PE: $12.6 \%$ ( $95 \% \mathrm{CI}-5.6$ to $34.3 \%$ ), the null hypothesis could not be rejected $(z=1.32, P=0.19)$. Heterogeneity was high $\left(I^{2}=98.73 \%\right)$. Of the 17 studies included in this meta-analysis, five studies' confidence intervals were not crossing the line of no effect, three above and two under zero (Fig. 2). The two moderators selected, only accounted for $4 \%$ of the heterogeneity and neither the aquatic ecosystem type $(z=-0.07, P=0.9)$ nor the material $(z=-1.55, P=0.12)$ had a significant influence on the occurrence of the PE. The test for residual heterogeneity was significant $\left(Q_{\mathrm{E}}=171.34\right.$,
$P<0.0001$ ), indicating that other moderators such as experimental conditions might have a stronger influence on the occurrence of the PE. Regarding publication biases, the funnel plot (Supplementary material ESM_3 Fig. 1) showed only asymmetry with small studies showing positive effect sizes. Thus, a publication bias towards reporting positive results might be affecting aquatic PE studies.

\section{Priming effect in aquatic ecosystems: less important than in soils}

Our meta-analysis showed scarce potential for significant PE in aquatic ecosystems. Although the overall PE was positive $(12.6 \%)$, the high heterogeneity across systems and within studies rendered this effect insignificant. Arguably, there are still relatively few studies addressing aquatic PE in a quantitative manner, and our results may therefore shift as more data becomes available and should be interpreted with caution.

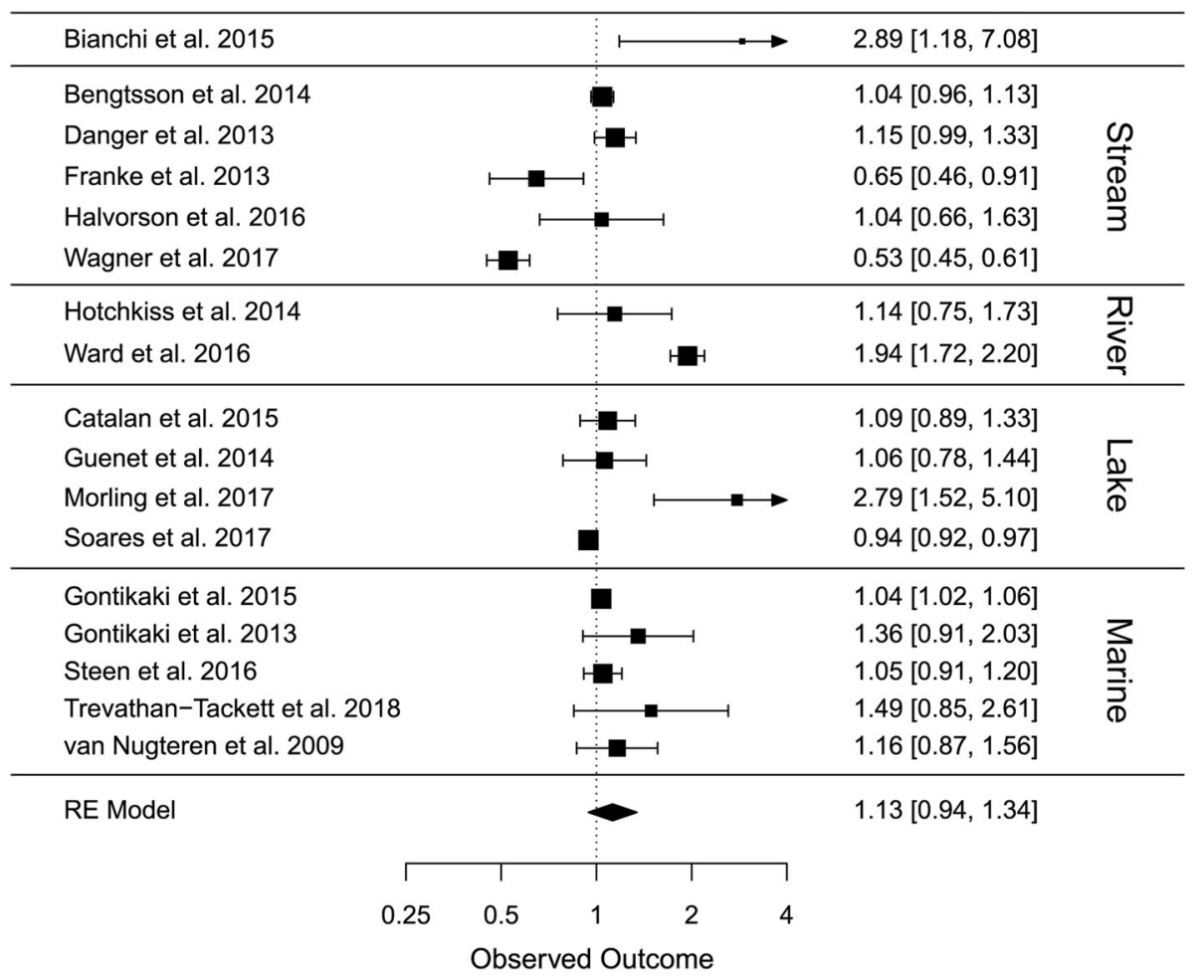

Fig. 2 Forest plot showing the log effect response of each study included in the meta-analysis. Size of symbols corresponds to the weighted effect of the corresponding study 
Guenet et al. (2010) presented a series of arguments why the PE should be a ubiquitous concept in ecological research across all ecosystems based on its occurrence across a wide range of terrestrial systems and the existence of some parallels between soils and aquatic ecosystems. However, the nonsignificant effect found in the present meta-analysis indicates that it is unlikely that aquatic PE will prove to be an important concept explaining aquatic $\mathrm{C}$ cycling. In contrast, $\mathrm{PE}$ in soils is considered to have a major impact on soil $\mathrm{C}$ cycling. A recent meta-analysis on soil PE identified it ranging from -48 to $>2000 \%$ with mostly positive effects. Soil PE was around $67 \%$ in the first 5 days following fresh $\mathrm{C}$ inputs and averaging all studies including longer term incubations, it was $37 \%$ (Luo et al., 2016). Nowadays, PE is considered as a major phenomenon in soil functioning and its $\mathrm{C}$ and nutrient cycles (Blagodatskaya \& Kuzyakov, 2008; Kuzyakov, 2010), although its mechanisms remain largely elusive (Keiluweit et al., 2015).

The soil matrix: essential for PE?

A major factor explaining the differences in biogeochemical processes and communities between soils and aquatic ecosystems is their physical structure. Soils inherit a complex matrix of minerals, OM and pore spaces that are filled with water and air in variable amounts (Bronick \& Lal, 2005; Schmidt et al., 2011). Until recently, the conventional view in soil sciences was that the intrinsic molecular structure of $\mathrm{OM}$ primarily controlled its processing (Marín-Spiotta et al., 2014). Recent results show that physical, chemical and biotic factors are the dominant controls of $C$ cycling in soils (Schmidt et al., 2011). This new view also changed the understanding of the mechanisms of PEs in soils. Rasmussen et al. (2007), for example, suggested that the magnitude of the PE might be partly controlled by the presence of soil mineral assemblages. Along the same lines, Keiluweit et al. (2015) showed that the release of oxalic acid by plant roots can promote $\mathrm{C}$ loss by releasing organic compounds from protective associations with minerals. Recent efforts to model PE in soils at the microscale suggest that small amounts of labile $\mathrm{C}$ trigger growth of microbial micro-colonies on soil particles. This explains positive PE on soil OM as the micro-colony is simply able to reach more native $\mathrm{OM}$ in the soil matrix as it grows larger (Kaiser et al., 2017). Thus, recent evidence points towards diverse biotic and abiotic mechanisms underlying PE in soils, comprising direct biotic and indirect abiotic mechanisms, many of which are linked to the nature of soil as a spatially complex mineral-OM matrix. In contrast, water, the matrix in aquatic environments, acts as a transport medium for $\mathrm{OM}$ and microorganisms, effectively smoothing out steep micro-gradients in OM concentration and microbial numbers. In addition, recent publications in the aquatic literature emphasize the role of intrinsic molecular characteristics on $\mathrm{OM}$ reactivity along the inland waters' continuum (Kellerman et al., 2015). Thus, differing dominant controls on OM degradation in soils versus aquatic ecosystems might influence the likelihood of PE occurrence in the two types of environments.

Aquatic ecosystems of course also contain matrixlike features associated to surfaces, such as benthonic structures in which sorption can have effects on microbial growth and $\mathrm{C}$ transformations by generating micro-gradients (Alldredge, 2000). Surfaces in aquatic ecosystems are either organic (e.g. leaves or detritus) or inorganic (e.g. cobbles or fine sediments) and covered by biofilms, a pool of microorganisms embedded in an exopolymeric matrix (Flemming \& Wingender, 2010). Within biofilms, micro-gradients become more pronounced, diffusion distances shrink, and potential for consortia development rises, leading to an enhancement of community metabolism (Battin et al., 2008) and higher turnover of OC (Sinsabaugh \& Findlay, 2003). Due to these spatial features, the potential for different sources of OM to interact (i.e. for PE) may be expected to be greater in sediments and biofilms than in the relatively homogenous water column of aquatic ecosystems. However, according to our analyses, the aquatic ecosystem type/material was not influencing occurrence of PE. Average PE was estimated at $67.8 \%$ for water column studies (median $=18.1 \%$, IQ range $=[-3.1,61.3], n=73)$, $22.5 \%($ median $=6.1 \%$, IQ range $=[-28.0,24.8]$, $n=38$ ) for sediment-based studies and $19.6 \%$ (median $=1.8$, IQ range $=[-5.6,16.8], n=7$ ) for leaf litter biofilm studies (Fig. 1b). Interestingly, studies in aquatic environments with more heterogeneous structures such as benthonic compartments are still underrepresented in the literature on non-additive effects and sediments in lakes have not been considered to this date (Table 1). 
Is aquatic OM different from soil OM?

A mechanism commonly proposed to explain soil PE is referred to as nutrient mining or nutrient scavenging. It implies a stimulation of microbial growth by the labile OM pool, which aggravates inorganic nutrient limitation subsequently increasing mineralization of the recalcitrant pool that contains higher concentrations of nutrients (Dijkstra et al., 2013; Chen et al., 2014). The caveat of this theory is the supposedly higher amount of nutrients (e.g. N, P) in the recalcitrant OM pool compared to the labile OM pool in soils. Although this assumption might generally hold true for soil OM, aquatic OM may in general be more $\mathrm{N}$-rich (Meyers, 1994). This is especially true for algal OM (Kendall et al., 2001) which is often considered as the labile OM pool in aquatic PE studies. In addition, aquatic $\mathrm{OM}$ is not necessarily intrinsically recalcitrant, and individual compounds may be protected from degradation through a dilution effect (Arrieta et al., 2015).

Aquatic environments host different microbial communities than soils

The occurrence of PE in aquatic and terrestrial ecosystems has often been explained by an interplay between microbial communities (Kuzyakov, 2002; Guenet et al., 2010). When OM from different sources mixes at ecotones in aquatic ecosystems, there is usually a simultaneous and inseparable mixing of microorganisms from each source which might cause changes in the function of the microbial community. In contrast, soil is typically the main source of microbial biomass and diversity in a soil PE context. This may be an important distinction between aquatic and soil environments, giving the composition and function of the microbial communities of the respective pools a greater role for non-additive effects in aquatic environments than in soils.

A key difference between soils and aquatic ecosystems with regards to non-additive effects on OM degradation might lie in the fungal community. A higher relevance of the fungal community in the rhizosphere is likely. Fungi have been proposed as key players on PE, as degraders of the recalcitrant OM after the supply of enzymes and energy from the other microbial community (Guenet et al., 2010). Although the knowledge is scarce, as aquatic fungal diversity is still highly underexplored (Wurzbacher et al., 2010; Grossart \& Rojas-Jimenez, 2016), new results suggest that soil and aquatic microbial communities differ in the occurrence and diversity of fungi (Bärlocher \& Boddy, 2016) and soils encounter a higher fungal diversity than aquatic habitats (Bärlocher \& Boddy, 2016). Therefore, if fungi play an important role in PE, the potential for PE occurrence might be smaller in aquatic ecosystems. However, fungal research in aquatic ecosystems is often restricted to specific groups, such as aquatic hyphomycetes (involved in leaf litter degradation; Bärlocher, 1992) or parasitic chytrids involved in food web dynamics ("mycoloop") (Kagami et al., 2014), limiting conclusions of the role of fungi in biogeochemical processes. Recent results suggest that aquatic fungal communities exhibit a high habitat specificity with highest diversities in biofilms and lower diversity in the water column (Wurzbacher et al., 2016). Although this could hint towards a higher potential of syntrophic interactions-and thus a positive PE-in biofilm-dominated habitats such as macrophytes or sediments, our metaanalysis revealed no significant differences on PE occurrence among materials. This might point, on the one hand, towards a negligible role of syntrophy between bacteria and fungi in aquatic ecosystems or, on the other hand, towards an underrepresentation of aquatic PE studies in biofilm-dominated habitats.

A divergent supply of OM sources between soils and aquatic ecosystems can also regulate the dynamics and metabolic activity of the heterotrophic bacterial community. An example of this is dormancy, a reversible state of low metabolic activity that microbes can enter when the environmental conditions are less favourable (Lennon \& Jones, 2011). Dormancy is a widely distributed trait for microbes that helps them to deal with environmental variability. The number of dormant cells in soils is twice as high as in fresh- or marine waters (Lennon \& Jones, 2011). Since one condition leading to dormancy is starvation or resource limitation of the microbes, a pulse of fresh and labile OM to soils can potentially "reactivate" a much larger number of dormant microbes in this environment than in an aquatic ecosystem. The higher turnover of microbial cells in the water column of aquatic ecosystems (Tranvik, 1992), reducing the number of dormant cells, might also reduce the effects of pulsed OM inputs in a system compared with soils. 


\section{Shortcomings of the PE concept and alternative conceptual avenues}

The concept of PE was developed in soils to explain a stimulation of $\mathrm{OM}$ degradation in response to labile organic additions, thus to describe positive $\mathrm{PE}$ (Bingeman et al., 1953). Therefore, although the term "negative priming" is now being applied to the opposite scenario-inhibition of OM degradation upon labile additions-it remains counterintuitive. The great interest in positive PE relies on the fact that a net increase in OM degradation can have great consequences for local and global C cycles (Regnier et al., 2013). Although the opposite is conceptually true [i.e. a net decrease in OM degradation could transform an ecosystem into a $\mathrm{C}$ sink (Wagner et al., 2017)], negative priming is a consequence of the "labile" OM source being preferentially used, therefore, without a direct implication on the system net $\mathrm{C}$ budget. This is the first reason why we suggest the term "interactive effects" over priming effects, to avoid biasing the interpretation of results a priori. This may be especially important in aquatic environments where, according to the results of our meta-analysis, OM degradation was generally not significantly inhibited or stimulated by the input of labile OM (Fig. 2), although a small number of the studies displayed consistent non-additive effects that were either only positive (e.g. Ward et al., 2016) or negative (e.g. Wagner et al., 2017).

Another troubling aspect of the PE concept is the attribution of pools of $\mathrm{OM}$ as either "labile" or "recalcitrant", assuming that when they mix one will prime the degradation of the other. Ecotones in aquatic ecosystems (see Introduction section for examples) do not necessarily correspond to groups of compounds with specific contrasting properties in terms of bioavailability. Within these converging OM pools, a continuum of reactivities is guaranteed (Mostovaya et al., 2017), and the chemical composition and diversity of OM reflects the biogeochemical histories of each pool (Kellerman et al., 2015). Thus, a more useful approach than classifying OM pools based on presumed bioavailability may be to acknowledge the range of different molecular compounds included in distinct $\mathrm{OM}$ sources. This is our second reason to suggest the use of "interactive effects" instead of PE.

The recent development and ease of access to massspectrometry tools to analyse molecular composition and diversity of environmental OM (Moran et al., 2016), allows tracing of interactions among specific $\mathrm{OM}$ compounds. For example, when two different $\mathrm{OM}$ pools meet at an ecotone, an increase in the overall molecular diversity of the resulting mix is to be expected. Molecular diversity may influence OC degradation potentials and rates in several ways. Indeed, the role of resource diversity on OC degradation processes has been studied independent of the concept of PE, and non-additive effects of mixed resources have been detected. For example, mixing of leaf litter from different species of deciduous trees has been shown to sometimes stimulate litter breakdown in incubation experiments in streams compared to that when single-species leaf litter is incubated (Kominoski et al., 2007). Functional traits, presumably related to chemical composition of each litter type, were determined to predict non-additive leaf litter mixing effects, although leaf chemical composition was not determined in these experiments (Lecerf et al., 2016).

Analogous to $\mathrm{OM}$ chemical composition, distinct source pools of OM host and transport different microbial communities. The role of microbial diversity for ecosystem function is a highly relevant yet debated topic with regards to the OM degradation function (Moran et al., 2016). Several studies have suggested a positive relationship between bacterial diversity and OM degradation (Cardinale et al., 2006) while others have demonstrated that a single bacterial strain could degrade seawater DOM equally well as a natural consortium of marine bacteria (Pedler et al., 2014). So far, microbial composition or diversity has not been explicitly manipulated with the aim to specifically test their influence on non-additive interactive effects, and therefore their role cannot be estimated. We think that taking chemical and microbial diversity into account when studying interactive effects on aquatic OM processing could lead to greater mechanistic insights (e.g. Logue et al., 2016; Lucas et al., 2016) than the approaches focusing on lability/ recalcitrance have offered so far.

\section{Conclusions and outlook}

Interactive effects of aquatic OM pools mixing can influence the mineralization of globally relevant $\mathrm{C}$ stocks. In the last decade, most of the studies on this 
understudied topic in aquatic sciences have been framed under the umbrella of the PE concept. However, the PE concept, originated in soil sciences, rests on some assumptions that may limit its application, interpretation and relevance in aquatic ecosystems. Through a meta-analysis of studies dealing with PEs in aquatic contexts, we have shown that mixing of $\mathrm{C}$ sources of different origins does not generally seem to cause a non-additive interactive effect on OM degradation in aquatic environments. However, individual studies reported both no effect and stimulation and/or inhibition of OM degradation, suggesting that these effects are highly context dependent in aquatic ecosystems. In order for future studies to achieve a more mechanistic understanding of what drives the interactive effects of OM pools, we suggest to

- Focus research on ecologically relevant ecotones, including the micro-scale, where OM pools of contrasting chemical properties and origin mix, regardless of whether these pools can be considered labile or recalcitrant. Understudied but potentially relevant ecotones include freshwater sediments receiving algal inputs and groundwater OM exposed to surface water infiltration.

- Determine the molecular and stoichiometric compositions of each OM pool, its associated microbial community and the functional diversity of the communities that co-occur with the respective $\mathrm{OM}$ pools. They can plausibly affect degradation rates and should also be taken into account. Experiments that separate OM mixing from mixing of the associated microbial communities by excluding microbial cells from one pool would be useful for addressing the role of microbial community composition and function on non-additive effects.

- Design experiments targeting mechanisms explaining interactive $\mathrm{OM}$ degradation dynamics for specific situations where available data suggest consistent non-additive effects, whether positive (e.g. rivers) or negative (e.g. stream biofilms). Stable isotope labelling approaches followed by compound-specific isotope analysis, such as DNA/ RNA stable isotope probing (SIP) or fatty acid and amino acid isotope ratio mass spectrometry, could reveal what organisms and molecules are involved in these interactions.

To understand the patterns in relation to nonadditive interactions of $\mathrm{OM}$ pools in aquatic ecosystems, we emphasize the need to study the underlying mechanisms and shift from simple proofof-concept, towards approaches seeking a better mechanistic understanding. We encourage more studies that quantify OM degradation of separate but interacting $\mathrm{OM}$ pools by employing stable isotope labelling or other appropriate methods (e.g. highresolution molecular methods). Further, we encourage taking advantage of recent technical advances allowing to better link microbial ecology and geochemistry through informatics (Moran et al., 2016) to re-visit and redefine the microbial mechanisms behind non-additive $\mathrm{OM}$ interactions.

Acknowledgements We gratefully acknowledge the support during the meta-analysis by Helmut Hillebrand and Nicholas Marino. We are very grateful for the thorough review and comments by two anonymous reviewers that greatly improved the manuscript. MMB was supported by a Marie Curie Individual Fellowship (PRIMA, EU-FP7). KA was financially supported by the German Research Foundation (DFG) in the form of a DFG Research Fellowship (AT 185/1-1) and NC held a Juan de la Cierva (FJCI-2014-23064) and a Beatriu de Pinós (BP-2016-00215) postdoctoral grants.

Open Access This article is distributed under the terms of the Creative Commons Attribution 4.0 International License (http:// creativecommons.org/licenses/by/4.0/), which permits unrestricted use, distribution, and reproduction in any medium, provided you give appropriate credit to the original author(s) and the source, provide a link to the Creative Commons license, and indicate if changes were made.

Author contributions All authors contributed equally to the conception of the work, the data acquisition and analysis, and their interpretation. All authors approved of the final version of this manuscript and author order was determined by coin-flip.

\section{References}

Alldredge, A. L., 2000. Interstitial dissolved organic carbon (DOC) concentrations within sinking marine aggregates and their potential contribution to carbon flux. Limnology and Oceanography 45: 1245-1253.

Arrieta, J. M., E. Mayol, R. L. Hansman, G. J. Herndl, T. Dittmar \& C. M. Duarte, 2015. Dilution limits dissolved organic carbon utilization in the deep ocean. Ocean Chemistry 348: 331-333.

Battin, T. J., L. A. Kaplan, S. Findlay, C. S. Hopkinson, E. Marti, A. I. Packman, J. D. Newbold \& F. Sabater, 2008. Biophysical controls on organic carbon fluxes in fluvial networks. Nature Geoscience 1: 95-100. 
Bengtsson, M. M., K. Wagner, N. R. Burns, E. R. Herberg, W. Wanek, L. A. Kaplan \& T. J. Battin, 2014. No evidence of aquatic priming effects in hyporheic zone microcosms. Scientific Reports 4: 5187.

Bianchi, T. S., 2007. Biogeochemistry of Estuaries. Oxford University Press, New York.

Bianchi, T. S., 2011. The role of terrestrially derived organic carbon in the coastal ocean: a changing paradigm and the priming effect. Proceedings of the National Academy of Sciences 108: 19473-19481.

Bianchi, T. S., D. C. O. Thornton, S. A. Yvon-Lewis, G. M. King, T. I. Eglinton, M. R. Shields, N. D. Ward \& J. Curtis, 2015. Positive priming of terrestrially derived dissolved organic matter in a freshwater microcosm system. Geophysical Research Letters 42: 5460-5467.

Billen, G., C. Lancelot, M. Meybeck, R. F. C. Mantoura, J. M. Martin \& R. Wollast, 1991. N, P and Si retention along the aquatic continuum from land to ocean. In Mantoura, R. F. C., J. M. Martin \& R. Wollast (eds), Ocean Margin Processes in Global Change. Wiley, Chichester: 19-44.

Bingeman, C. W., J. E. Varner \& W. P. Martin, 1953. The effect of the addition of organic materials on the decomposition of an organic soil. Soil Science Society of America Journal Madison, WI 17: 34-38.

Blagodatskaya, E. \& Y. Kuzyakov, 2008. Mechanisms of real and apparent priming effects and their dependence on soil microbial biomass and community structure: critical review. Biology and Fertility of Soils 45: 115-131.

Blanchet, M., O. Pringault, C. Panagiotopoulos, D. Lefèvre, B. Charrière, J. F. Ghiglione, C. Fernandez, F. L. Aparicio, C. Marrasé, P. Catala, L. Oriol, J. Caparros \& F. Joux, 2017. When riverine dissolved organic matter (DOM) meets labile DOM in coastal waters: changes in bacterial community activity and composition. Aquatic Sciences 79: 27-43.

Bronick, C. J. \& R. Lal, 2005. Soil structure and management: a review. Geoderma 124: 3-22.

Bärlocher, F., 1992. The Ecology of Aquatic Hyphomycetes. Springer, Berlin.

Bärlocher, F. \& L. Boddy, 2016. Aquatic fungal ecology-how does it differ from terrestrial? Fungal Ecology 19: 5-13.

Cardinale, B. J., D. S. Srivastava, J. E. Duffy, J. P. Wright, A. L. Downing, M. Sankaran \& C. Jouseau, 2006. Effects of biodiversity on the functioning of trophic groups and ecosystems. Nature 443: 989-992.

Catalán, N., A. M. Kellerman, H. Peter, F. Carmona \& L. J. Tranvik, 2015. Absence of a priming effect on dissolved organic carbon degradation in lake water. Limnology and Oceanography 60: 159-168.

Catalán, N., R. Marcé, D. N. Kothawala \& L. J. Tranvik, 2016. Organic carbon decomposition rates controlled by water retention time across inland waters. Nature Geoscience 9: $1-7$.

Chen, R., M. Senbayram, S. Blagodatsky, O. Myachina, K. Dittert, X. Lin, E. Blagodatskaya \& Y. Kuzyakov, 2014. Soil $\mathrm{C}$ and $\mathrm{N}$ availability determine the priming effect: microbial $\mathrm{N}$ mining and stoichiometric decomposition theories. Global Change Biology 20: 2356-2367.

Ciais, P., C. Sabine, G. Bala, L. Bopp, V. Brovkin, J. Canadell, A. Chhabra, R. DeFries, J. Galloway, M. Heimann, C. Jones, C. Le Quéré, R. B. Myneni, S. Piao, \& P. Thornton,
2013. Carbon and Other Biogeochemical Cycles. In Stocker, T., Qin, D., Plattner, G.-K., Tignor, M., Allen, S., Boschung, J., Nauels, A., Xia, Y., Bex, V., \& Midgley, P. (eds), Climate Change 2013-The Physical Science Basis Contribution of Working Group I to the Fifth Assessment Report of the Intergovernmental Panel on Climate Change. Cambridge University Press, Cambridge: 465-570.

Clements, F. E., 1905. Research Methods in Ecology. University Publishing Company, Lincoln, NE.

Cole, J. J., N. F. Caraco, G. W. Kling \& T. K. Kratz, 1994. Carbon dioxide supersaturation in the surface waters of lakes. Science 265: 1568-1570.

Cole, J. J., Y. T. Prairie, N. F. Caraco, W. H. McDowell, L. J. Tranvik, R. G. Striegl, C. M. Duarte, P. Kortelainen, J. A. Downing, J. J. Middelburg \& J. Melack, 2007. Plumbing the global carbon cycle: integrating inland waters into the terrestrial carbon budget. Ecosystems 10: 172-185.

Danger, M., J. Cornut, E. Chauvet, P. Chavez \& A. Elger, 2013. Benthic algae stimulate leaf litter decomposition in detritus-based headwater streams: a case of aquatic priming effect? Ecology 94: 1604-1613.

Del Giorgio, P. A., J. J. Cole, N. F. Caraco \& R. H. Peters, 1999. Linking planktonic biomass and metabolism to net gas fluxes in northern temperate lakes. Ecology 80: 1422-1431.

Dijkstra, F. A., Y. Carrillo, E. Pendall \& J. A. Morgan, 2013. Rhizosphere priming: a nutrient perspective. Frontiers in Microbiology 4: 1-8.

Dorado-García, I., J. Syväranta, S. P. Devlin, J. M. MedinaSánchez \& R. I. Jones, 2015. Experimental assessment of a possible microbial priming effect in a humic boreal lake. Aquatic Sciences 78: 191-202.

Duval, S. \& R. Tweedie, 2000. Trim and fill: a simple funnelplot-based method of testing and adjusting for publication bias in meta-analysis. Biometrics 56: 455-463.

Flemming, H.-C. \& J. Wingender, 2010. The biofilm matrix. Nature Reviews Microbiology 8: 623-633.

Franke, D., E. J. Bonnell \& S. E. Ziegler, 2013. Mineralisation of dissolved organic matter by heterotrophic stream biofilm communities in a large boreal catchment. Freshwater Biology 58: 2007-2026.

Gambrell, R. P. \& W. H. Patrick Jr., 1978. Chemical and microbiological properties of anaerobic soils and sediments. In Hook, D. D. \& R. M. M. Crawfors (eds), Plant Life in Anaerobic Environments. Ann Arbor Science Publications, Ann Arbor: 375-423.

Gontikaki, E., B. Thornton, V. A. I. Huvenne \& U. Witte, 2013. Negative priming effect on organic matter mineralisation in NE atlantic slope sediments. PLoS ONE 8: e67722.

Gontikaki, E., B. Thornton, T. Cornulier \& U. Witte, 2015. Occurrence of priming in the degradation of lignocellulose in marine sediments. PLoS ONE 10: 1-13.

Grossart, H.-P. \& K. Rojas-Jimenez, 2016. Aquatic fungi: targeting the forgotten in microbial ecology. Current Opinion in Microbiology 31: 140-145.

Guenet, B., M. Danger, L. Abbadie \& G. Lacroix, 2010. Priming effect: bridging the gap between terrestrial and aquatic ecology. Ecology 91: 2850-2861.

Guenet, B., M. Danger, L. Harrault, B. Allard, M. Jauset-Alcala, G. Bardoux, D. Benest, L. Abbadie \& G. Lacroix, 2014. Fast mineralization of land-born $\mathrm{C}$ in inland waters: first 
experimental evidences of aquatic priming effect. Hydrobiologia 721: 35-44.

Guenet, B., M. Camino-Serrano, P. Ciais, M. Tifafi, F. Maignan, J. L. Soong \& I. A. Janssens, 2018. Impact of priming on global soil carbon stocks. Global Change Biology 24(5): 1873-1883.

Gurevitch, J. \& L. V. Hedges, 2001. Meta-analysis: combining the results of independent experiments. In Gurevitch, J. \& S. M. Scheiner (eds), Design and Analysis of Ecological Experiments. Chapman \& Hall, New York: 347-369.

Halvorson, H. M., E. E. Scott, S. A. Entrekin, M. A. EvansWhite \& J. T. Scott, 2016. Light and dissolved phosphorus interactively affect microbial metabolism, stoichiometry and decomposition of leaf litter. Freshwater Biology 61: 1006-1019.

Hannides, A. K. \& R. C. Aller, 2016. Priming effect of benthic gastropod mucus on sedimentary organic matter remineralization. Limnology and Oceanography 61: 1640-1650.

Hansell, D. A., 2013. Recalcitrant dissolved organic carbon fractions. Annual Review of Marine Science 5: 421-445.

Hedges, J. I., 1992. Global biogeochemical cycles: progress and problems. Marine Chemistry 39: 67-93.

Hedges, L. V., J. Gurevitch \& P. S. Curtis, 1999. The metaanalysis of response ratios in experimental ecology. Ecology 80: 1150-1156.

Hillebrand, H. \& J. Gurevitch, 2016. Meta-Analysis and Systematic Reviews in Ecology eLS. Wiley, Chichester: 1-11.

Hintze, J. L. \& R. D. Nelson, 1998. Violin plots: a box plotdensity trace synergism. The American Statistician 52: 181-184.

Hofmann, R. \& C. Griebler, 2018. DOM and bacterial growth efficiency in oligotrophic groundwater: absence of priming and co-limitation by organic carbon and phosphorus. Aquatic Microbial Ecology 81: 55-71.

Hotchkiss, E. R., R. O. Hall, M. A. Baker, E. J. Rosi-Marshall \& J. L. Tank, 2014. Modeling priming effects on microbial consumption of dissolved organic carbon in rivers. Journal of Geophysical Research: Biogeosciences 119: 982-995.

Huo, C., Y. Luo \& W. Cheng, 2017. Soil biology \& biochemistry rhizosphere priming effect: a meta-analysis. Soil Biology and Biochemistry 111: 78-84.

Jiao, N., C. Robinson, F. Azam, H. Thomas, F. Baltar, H. Dang, N. J. Hardman-Mountford, M. Johnson, D. L. Kirchman, B. P. Koch, L. Legendre, C. Li, J. Liu, T. Luo, Y. W. Luo, A. Mitra, A. Romanou, K. Tang, X. Wang, C. Zhang \& R. Zhang, 2014. Mechanisms of microbial carbon sequestration in the ocean-future research directions. Biogeosciences 11: 5285-5306.

Kagami, M., T. Miki \& G. Takimoto, 2014. Mycoloop: chytrids in aquatic food webs. Frontiers in Microbiology 5: 1-9.

Kaiser, C., U. Dieckmann, \& O. Franklin, 2017. The rhizosphere priming effect explained by microscale interactions among enzyme producing microbes. In EGU General Assembly Conference Abstracts, Vol. 19: 19214.

Kankaala, P., J. Lopez Bellido, A. Ojala, T. Tulonen \& R. I. Jones, 2013. Variable production by different pelagic energy mobilizers in Boreal lakes. Ecosystems 16: 1152-1164.

Keiluweit, M., J. J. Bougoure, P. S. Nico, J. Pett-Ridge, P. K. Weber \& M. Kleber, 2015. Mineral protection of soil carbon counteracted by root exudates. Nature Climate Change 5: 588-595.

Kellerman, A. M., D. N. Kothawala, T. Dittmar \& L. J. Tranvik, 2015. Persistence of dissolved organic matter in lakes related to its molecular characteristics. Nature Geoscience 8: 454-459.

Kendall, C., S. R. Silva \& V. J. Kelly, 2001. Carbon and nitrogen isotopic compositions of particulate organic matter in four large river systems across the United States. Hydrological Processes 15: 1301-1346.

Koch, B. P., G. Kattner, M. Witt \& U. Passow, 2014. Molecular insights into the microbial formation of marine dissolved organic matter: recalcitrant or labile? Biogeosciences 11: 4173-4190.

Kominoski, J. S., C. M. Pringle, B. A. Ball, M. A. Bradford, D. C. Coleman, D. B. Hall \& M. D. Hunter, 2007. Nonadditive effects of leaf litter species diversity on breakdown dynamics in a detritus-based stream. Ecology 88: 1167-1176.

Krause, S., J. Lewandowski, N. B. Grimm, D. M. Hannah, G. Pinay, K. McDonald, E. Martí, A. Argerich, L. Pfister, J. Klaus, T. J. Battin, S. T. Larned, J. Schelker, J. Fleckenstein, C. Schmidt, M. O. Rivett, G. Watts, F. Sabater, A. Sorolla \& V. Turk, 2017. Ecohydrological interfaces as hot spots of ecosystem processes. Water Resources Research 53: 6359-6376.

Kuehn, K. A., S. N. Francoeur, R. H. Findlay \& R. K. Neely, 2014. Priming in the microbial landscape: periphytic algal stimulation of litter-associated microbial decomposers. Ecology 95: 749-762.

Kuzyakov, Y., 2002. Review: factors affecting rhizosphere priming effects. Journal of Plant Nutrition and Soil Science 165: 382-396.

Kuzyakov, Y., 2010. Priming effects: interactions between living and dead organic matter. Soil Biology and Biochemistry 42: 1363-1371.

Kuzyakov, Y., J. K. Friedel \& K. Stahr, 2000. Review of mechanisms and quantification of priming effects. Soil Biology and Biochemistry 32: 1485-1498.

Lecerf, A., G. Marie, J. S. Kominoski, C. J. Leroy, C. M. Swan, A. Lecerf, G. Marie, J. S. Kominoski, C. J. Leroy, C. Bernadet \& C. M. Swan, 2016. Incubation time, functional litter diversity, and habitat characteristics predict littermixing effects on decomposition. Ecology 92: 160-169.

Lennon, J. T. \& S. E. Jones, 2011. Microbial seed banks: the ecological and evolutionary implications of dormancy. Nature Reviews Microbiology 9: 119-130.

Logue, J. B., C. A. Stedmon, A. M. Kellerman, N. J. Nielsen, A. F. Andersson, H. Laudon, E. S. Lindström \& E. S. Kritzberg, 2016. Experimental insights into the importance of aquatic bacterial community composition to the degradation of dissolved organic matter. The ISME Journal 10: 533-545.

Lucas, J., I. Koester, A. Wichels, J. Niggemann, T. Dittmar, U. Callies, K. H. Wiltshire \& G. Gerdts, 2016. Short-term dynamics of north sea bacterioplankton-dissolved organic matter coherence on molecular level. Frontiers in Microbiology 7: 321.

Luo, Z., E. Wang \& O. J. Sun, 2016. A meta-analysis of the temporal dynamics of priming soil carbon decomposition 
by fresh carbon inputs across ecosystems. Soil Biology and Biochemistry 101: 96-103.

Löhnis, F., 1926. Nitrogen availability of green manures. Soil Science 22: 253-290.

Mann, P. J., T. I. Eglinton, C. P. McIntyre, N. Zimov, A. Davydova, J. E. Vonk, R. M. Holmes \& R. G. M. Spencer, 2015. Utilization of ancient permafrost carbon in headwaters of Arctic fluvial networks. Nature Communications 6: 7856.

Marín-Spiotta, E., K. E. Gruley, J. Crawford, E. E. Atkinson, J. R. Miesel, S. Greene, C. Cardona-Correa \& R. G. M. Spencer, 2014. Paradigm shifts in soil organic matter research affect interpretations of aquatic carbon cycling: transcending disciplinary and ecosystem boundaries. Biogeochemistry 117: 279-297.

McCallister, S. L. \& P. A. del Giorgio, 2012. Evidence for the respiration of ancient terrestrial organic $\mathrm{C}$ in northern temperate lakes and streams. Proceedings of the National Academy of Sciences of the United States of America 109: 16963-16968.

Meyers, P. A., 1994. Preservation of elemental and isotopic source identification of sedimentary organic matter. Chemical Geology 114: 289-302.

Mitsch, W. J. \& J. G. Gosselink, 2007. Wetlands. Wiley, New York.

Moore, W. S., 1996. Large groundwater inputs to coastal waters revealed by $226 \mathrm{Ra}$ enrichments. Nature 380 : 612-614.

Moran, M. A., E. B. Kujawinski, A. Stubbins, R. Fatland, L. I. Aluwihare, A. Buchan, B. C. Crump, P. C. Dorrestein, S. T. Dyhrman, N. J. Hess, B. Howe, K. Longnecker, P. M. Medeiros, J. Niggemann, I. Obernosterer, D. J. Repeta \& J. R. Waldbauer, 2016. Deciphering ocean carbon in a changing world. Proceedings of the National Academy of Sciences 113: 3143-3151.

Morling, K., J. Raeke, N. Kamjunke, T. Reemtsma \& J. Tittel, 2017. Tracing aquatic priming effect during microbial decomposition of terrestrial dissolved organic carbon in chemostat experiments. Microbial Ecology 74: 534-549.

Mostovaya, A., J. A. Hawkes, B. Koehler, T. Dittmar \& L. J. Tranvik, 2017. Emergence of the reactivity continuum of organic matter from kinetics of a multitude of individual molecular constituents. Environmental Science \& Technology 51: 11571-11579.

Pedler, B. E., L. I. Aluwihare \& F. Azam, 2014. Single bacterial strain capable of significant contribution to carbon cycling in the surface ocean. Proceedings of the National Academy of Sciences of the United States of America 111: 7202-7207.

R Core Team, 2016. R: A Language and Environment for Statistical Computing. R Foundation for Statistical Computing, Vienna, Austria.

Rasmussen, C., R. J. Southard \& W. R. Horwath, 2007. Soil mineralogy affects conifer forest soil carbon source utilization and microbial priming. Soil Science Society of America Journal 71: 1141-1150.

Raymond, P. A., J. E. Saiers \& W. V. Sobczak, 2016. Hydrological and biogeochemical controls on watershed dissolved organic matter transport: pulse-shunt concept. Ecology 97: 5-16.

Regnier, P., P. Friedlingstein, P. Ciais, F. T. Mackenzie, N. Gruber, I. A. Janssens, G. G. Laruelle, R. Lauerwald, S.
Luyssaert, A. J. Andersson, S. Arndt, C. Arnosti, A. V. Borges, A. W. Dale, A. Gallego-Sala, Y. Goddéris, N. Goossens, J. Hartmann, C. Heinze, T. Ilyina, F. Joos, D. E. LaRowe, J. Leifeld, F. J. R. Meysman, G. Munhoven, P. A. Raymond, R. Spahni, P. Suntharalingam \& M. Thullner, 2013. Anthropogenic perturbation of the carbon fluxes from land to ocean. Nature Geoscience 6: 597-607.

Schmidt, M. W. I., M. S. Torn, S. Abiven, T. Dittmar, G. Guggenberger, I. A. Janssens, M. Kleber, I. Kögel-Knabner, J. Lehmann, D. A. C. Manning, P. Nannipieri, D. P. Rasse, S. Weiner \& S. E. Trumbore, 2011. Persistence of soil organic matter as an ecosystem property. Nature 478: 49-56.

Seidel, M., P. L. Yager, N. D. Ward, E. J. Carpenter, H. R. Gomes, A. V. Krusche, J. E. Richey, T. Dittmar \& P. M. Medeiros, 2015. Molecular-level changes of dissolved organic matter along the Amazon River-to-ocean continuum. Marine Chemistry 177: 218-231.

Sinsabaugh, R. L. \& S. E. G. Findlay, 2003. Dissolved organic matter: out of the black box into the mainstream. In Sinsabaugh, R. L. \& S. E. G. Findlay (eds), Aquatic Ecosystems: Interactivity of Dissolved Organic Matter. Elsevier Science, New York: 479-496.

Soares, M., E. S. Kritzberg \& J. Rousk, 2017. Labile carbon "primes" fungal use of nitrogen from submerged leaf litter. FEMS Microbiology Ecology 93: 1-10.

Steen, A. D., L. N. M. Quigley \& A. Buchan, 2016. Evidence for the priming effect in a planktonic estuarine microbial community. Frontiers in Marine Science 3: 6.

Sterne, J. A. C. \& R. M. Harbord, 2004. Funnel plots in metaanalysis. The Stata Journal 4: 127-141.

Stutter, M. I. \& J. Cains, 2015. The mineralisation of dissolved organic matter recovered from temperate waterbodies during summer. Aquatic Sciences 78: 447-462.

Tranvik, L. J., 1992. Allochthonous dissolved organic matter as an energy source for pelagic bacteria and the concept of the microbial loop. Hydrobiologia 229: 107-114.

Tranvik, L. J., J. A. Downing, J. B. Cotner, S. A. Loiselle, R. G. Striegl, T. J. Ballatore, P. Dillon, K. Finlay, K. Fortino, L. B. Knoll, P. L. Kortelainen, T. Kutser, S. Larsen, I. Laurion, D. M. Leech, S. L. McCallister, D. M. McKnight, J. M. Melack, E. Overholt, J. A. Porter, Y. T. Prairie, W. H. Renwick, F. Roland, B. S. Sherman, D. W. Schindler, S. Sobek, A. Tremblay, M. J. Vanni, A. M. Verschoor, E. von Wachenfeldt \& G. A. Weyhenmeyer, 2009. Lakes and reservoirs as regulators of carbon cycling and climate. Limnology and Oceanography 54: 2298-2314.

Trevathan-Tackett, S. M., A. C. G. Thomson, P. J. Ralph \& P. I. Macreadie, 2018. Fresh carbon inputs to seagrass sediments induce variable microbial priming responses. Science of the Total Environment 621: 663-669.

Vadeboncoeur, Y., M. J. Vander Zanden \& D. M. Lodge, 2002. Putting the lake back together: reintegrating benthic pathways into lake food web models. BioScience 52: 44-54.

van Nugteren, P., L. Moodley, G. J. Brummer, C. H. R. Heip, P. M. J. Herman \& J. J. Middelburg, 2009. Seafloor ecosystem functioning: the importance of organic matter priming. Marine Biology 156: 2277-2287.

Vannote, R. L., G. W. Minshall, K. W. Cummins, J. R. Sedell \& C. E. Cushing, 1980. The river continuum concept. 
Canadian Journal of Fisheries and Aquatic Sciences 37: 130-137.

Viechtbauer, W., 2010. Conducting meta-analyses in R with the metafor package. Journal of Statistical Software 36: 1-48.

Wagner, K., M. M. Bengtsson, R. H. Findlay, T. J. Battin \& A. J. Ulseth, 2017. High light intensity mediates a shift from allochthonous to autochthonous carbon use in phototrophic stream biofilms. Journal of Geophysical Research: Biogeosciences 122: 1806-1820.

Ward, N. D., T. S. Bianchi, H. O. Sawakuchi, W. Gagne-maynard, A. C. Cunha, D. C. Brito, V. Neu, A. D. M. Valerio, R. Silva, A. V. Krusche, J. E. Richey \& R. G. Keil, 2016. The reactivity of plant-derived organic matter and the potential importance of priming effects along the lower Amazon River. Journal of Geophysical Research: Biogeosciences 121: 1522-1539.
Wurzbacher, C. M., F. Bärlocher \& H.-P. Grossart, 2010. Fungi in lake ecosystems. Aquatic Microbial Ecology 59: 125-149.

Wurzbacher, C., N. Warthmann, E. Bourne, K. Attermeyer, M. Allgaier, J. R. Powell, H. Detering, S. Mbedi, H.-P. Grossart \& M. Monaghan, 2016. High habitat-specificity in fungal communities in oligo-mesotrophic, temperate Lake Stechlin (North-East Germany). MycoKeys 16: 17-44.

Wyatt, K. H. \& M. R. Turetsky, 2015. Algae alleviate carbon limitation of heterotrophic bacteria in a boreal peatland. Journal of Ecology 103: 1165-1171.

Xiong, S. \& C. Nilsson, 1997. Dynamics of leaf litter accumulation and its effects on riparian vegetation: a review. The Botanical Review 63: 240-264. 